\title{
Evaluasi Dedak Padi Kukus dan Suplementasi MHA (Methionine Hidroxy Analog) terhadap Kecernaan Nutrien Ransum Domba Lokal Jantan
}

\author{
W. P. S. Suprayogi ${ }^{1}$, S. D. Widyawati ${ }^{1}$ dan R. Hidayah ${ }^{2}$ \\ ${ }^{1}$ Program Studi Peternakan, Fakultas Pertanian Universitas Sebelas Maret, ${ }^{2}$ Sarjana Jurusan/Program \\ Studi Peternakan, Fakultas Pertanian Universitas Sebelas Maret \\ Jl. Ir. Sutami 36 A Surakarta 657126
}

\begin{abstract}
ABSTRAK
Penelitian ini bertujuan untuk mengetahui pengaruh pengukusan dedak padi dan suplementasi MHA terhadap kecernaan nutrien ransum domba lokal jantan. Penelitian menggunakan 12 ekor domba lokal jantan dengan bobot badan rata-rata 10,32 \pm 1,02 kg. Ransum perlakuan yang digunakan masing-masing untuk P0 (60 persen rumput raja +40 persen dedak padi), P1 (60 persen rumput raja +40 persen dedak padi kukus), P2 (60 persen rumput raja +40 persen dedak padi kukus $+1 \mathrm{~g}$ MHA). Rancangan percobaan adalah Rancangan Acak Lengkap (RAL) pola searah dengan 3 perlakuan. Masing-masing perlakuan terdiri dari empat ulangan. Parameter yang diamati meliputi konsumsi bahan kering, konsumsi bahan organik, kecernaan bahan kering, kecernaan bahan organik, nutritive value indeks bahan kering dan nutritive value indeks bahan organik. Data hasil perlakuan P0, P1, dan P2 berturut untuk konsumsi bahan kering adalah 960,024; 909,462; dan 926,399 g/ekor/hari, konsumsi bahan organik adalah 825,036; 772,665 dan 796,225 g/ekor/hari, kecernaan bahan kering dalam persen adalah 72,424; 73,050 dan 73,068, kecernaan bahan organik dalam persen adalah 75,989; 76,306 dan 76,239, nutritive value index bahan kering (NVIBK) adalah 695,396; 664,932 dan 677,654 g/ekor/hari dan nutritive value index bahan organik (NVIBO) adalah 626,894; 589,985 dan 607,649 g/ekor/hari. Hasil analisis variansi menunjukkan bahwa penggunaan dedak padi kukus dan penambahan MHA berbeda tidak nyata $(\mathrm{P}>0,05)$ terhadap konsumsi bahan kering, konsumsi bahan organik, kecernaan bahan kering, kecernaan bahan organik, nutritive value indeks bahan kering dan nutritive value indeks bahan organik. Dari hasil penelitian dapat diambil kesimpulan bahwa penggunaan dedak padi kukus dan penambahan MHA tidak mempengaruhi semua peubah yang diamati.
\end{abstract}

Kata Kunci : domba lokal jantan, dedak padi kukus, MHA, kecernaan

\section{Evaluation of Rice Bran Steaming and MHA (Methionine Hydroxy Analog) Supplementation on Nutrient Digestibility of Local Male Sheep}

\section{ABSTRACT}

The research aimed to know the effect of rice bran steaming and MHA supplementation on the increasing of nutrient digestibility of local male sheep. This research used 12 local male sheeps with average of body weight $10.32 \pm 1.02 \mathrm{~kg}$. Treatment of rations were for $P 0$ (60\% king grass + $40 \%$ bran), $P 1$ (60\% king grass $+40 \%$ steamed bran), P2 (60\% king grass $+40 \%$ steamed bran $+1 \mathrm{~g}$ MHA). Design used in research was Completely Randomized Design (CRD) in one-way pattern using 3 treatments. Each treatment consisted of 4 replications. Parameters observed were dry matter intake, organic matter intake, dry matter nutritive value index and organic matter nutritive value index. The result of treatment P0, P1, and P2 for dry matter intake were 960.024; 
909.426; and $926.399 \mathrm{~g} / \mathrm{head} /$ day respectively, organic matter intake were 825.036; 772.665; and $796.225 \mathrm{~g} / \mathrm{head} /$ day, organic matter digestibility in percent were 72.424; 73.050; and 73.068, organic matter digestibility in percent were 75.989; 76.306; and 76.239, dry matter nutritive value index were 695.396; 664.392; and $677.654 \mathrm{~g} / \mathrm{head} /$ day and organic matter nutritive value index were 626.894; 589.985; and $607.649 \mathrm{~g} / \mathrm{head} /$ day. The variance Analysis showed that the usage of steamed rice bran and adding of MHA given non significantly effect $(P>0.5)$ on dry matter intake, organic matter intake, dry matter digestibility, organic matter digestibility, dry matter nutritive value index, and organic matter nutritive value index. It can be concluded that the treatments did not affect variables that were measured.

Password : local male sheep, steamed bran, MHA, digestibility

\section{PENDAHULUAN}

Sistem pemeliharaan domba di Indonesia umumnya dilakukan secara tradisional dengan pemberian pakan yang masih tergantung pada hijauan saja dan sedikit sekali disediakan pakan penguat (konsentrat). Konsentrat merupakan pakan penguat yang diberikan untuk melengkapi kekurangan nutrien yang didapat dari pakan utama yaitu hijauan. Konsentrat mempunyai kandungan energi, protein, dan lemak yang relatif lebih tinggi dengan kandungan serat kasar yang rendah dibanding hijauan yang diberikan (Williamson dan Payne, 1993). Pengadaan konsentrat dalam usaha penggemukkan ternak domba sering menimbulkan kendala karena harganya yang mahal oleh karena itu perlu dicari bahan pakan yang murah dan belum dimanfaatkan secara maksimal sebagai bahan pakan dengan tetap memperhatikan nutrien yang terkandung didalam bahan pakan.

Pertanian di Indonesia banyak menghasilkan limbah sangat potensial sebagai pakan ternak dengan biaya yang murah yaitu dedak padi. Dedak padi memiliki kandungan protein yang cukup tinggi, sedangkan kandungan serat kasarnya dapat berubah - ubah tergantung pada perbandingan kulit yang ada.

Sentuhan teknologi guna meningkatkan utilitas dedak padi dapat dilakukan dengan cara pengukusan. Proses pengukusan diharapkan dapat melonggarkan ikatan pati sehingga terjadi pembebasan amilosa yang akan menyebabkan daya larutnya meningkat. Dengan demikian pelepasan energinya akan sejalan dengan pelepasan amonia sehingga akan lebih efisien dalam rumen (Manik, 1985).

Bahan baku utama dalam penyusunan konsentrat pada umumnya berasal dari bijibijian seperti jagung, limbah pertanian dan limbah agro-industri pengolahan hasil pertanian seperti misalnya dedak gandum, dedak padi, bungkil kacang tanah, bungkil kelapa, bungkil kedelai dan lain-lain. Bahan baku diatas ternyata tidak mampu menyediakan metionin yang cukup sehingga metionin perlu mendapatkan perhatian lebih (Dilaga, 1992). Metionin dapat digantikan sebagian besar oleh analognya yang dalam perdagangan disajikan dengan nama MHA. Formula MHA tersebut adalah (Dilaga,1992).

Ikatan pati pada dedak masih kuat. Pengukusan mengakibatkan sel-sel pati akan mengembang dan terjadi penguraian granula pati (Manik, 1985). Pada prinsipnya, proses pengukusan pati bertujuan untuk merenggangkan ikatan pati sehingga akan mempercepat pemecahan pati oleh mikroba rumen dan dengan demikian pelepasan energinya akan sejalan dengan pelepasan amonia dari senyawa nitrogen yang mudah dihidrolis. Sehingga amonia dapat digunakan lebih efisien dalam rumen (Szylit et. al., 1977 cit Manik 1985).

Sebagian besar bahan pakan kekurangan kandungan metionin, termasuk dedak padi 
sehingga untuk pemenuhannya diperlukan suplementasi melalui MHA. Suplementasi MHA dalam ransum, oleh enzim transaminase didalam tubuh akan diubah menjadi asam amino metionin. Metionin merupakan asam amino essensial yang dibutuhkan oleh hewan untuk pertumbuhan dan kesehatan normal dan harus tersedia dalam ransum, karena hewan tidak mampu mensintetis sendiri di dalam tubuhnya. Kekurangan metionin dalam ransum dapat menyebabkan merosotnya berat badan dan timbulnya kebiasaan makan bulu. Metionin berfungsi untuk pertumbuhan tulang, urat daging, kulit, bulu dan menggantikan jaringan tubuh yang rusak.

\section{MATERI DAN METODE}

Penelitian dilaksanakan selama 3 bulan pada tanggal 11 Agustus - 14 November 2009 di Kandang Percobaan Jatikuwung Jurusan Peternakan Fakultas Pertanian UNS. Analisis proksimat bahan pakan dilakukan di Laboratorium Nutrisi dan Makanan Ternak, Jurusan Peternakan dan analisa feses dilakukan di Laboratorium Biologi Tanah, Jurusan Ilmu Tanah, Fakultas Pertanian UNS.

Materi yang digunakan adalah 12 ekor domba jantan lepas sapih dengan bobot 10,32 \pm $1,02 \mathrm{~kg}$. Bahan ransum yang digunakan dalam penelitian ini terdiri dari rumput raja, dedak padi, dedak padi kukus, dan dedak padi kukus ditambah MHA. Pengukusan dilakukan pada suhu sekitar 1000C selama 60 menit. Kandungan nutrien bahan penyusun ransum dan susunan pakan beserta kandungan Tabel 1 dan 2. Ransum perlakuan yang diberikan sebagai berikut :

P0 $=$ Rumput raja $60 \%+$ dedak padi $40 \%$

$\mathrm{P} 1$ = Rumput raja $60 \%+$ dedak padi kukus $40 \%$

P2 = Rumput raja $60 \%+$ dedak padi kukus $40 \%+$ MHA $1 \mathrm{~g}(0,1 \%)$.

Tabel 1. Kandungan nutrien bahan pakan untuk ransum

\begin{tabular}{lccccccc}
\hline \multirow{2}{*}{ Bahan Pakan } & BK & PK & TDN & Ca & P & SK & Metionin \\
\cline { 2 - 7 } & \multicolumn{7}{c}{$(\%)$} \\
Rumput raja $^{(1)}$ & 88,26 & 15,31 & $61,92^{(5)}$ & 0,44 & 0,54 & 28 & $0,17^{(8)}$ \\
Dedak padi $^{(2)}$ & 90,38 & 7,6 & 51 & 0,1 & 1,15 & 27,8 & $0,1^{(8)}$ \\
Minyak sawit & - & - & $248,85^{(6)}$ & - & - & - & - \\
Urea & - & $281^{(3)}$ & - & - & - & - & - \\
MHA & - & - & - & - & - & - & $86^{(7)}$ \\
Premix & - & - & - & $45^{(4)}$ & $35^{(4)}$ & - & - \\
Molases $^{(2)}$ & 77 & 4,2 & 75,3 & 0,84 & 0,09 & 7,7 & $0,03^{(8)}$ \\
\hline
\end{tabular}

Sumber:

1) Hasil Analisis di Laboratorium Biologi Tanah FP UNS

2) Hartadi et al., 1990

3) Belasco, 1954

4) Produksi Eka Poultry Semarang (mineral BR)

5) Hartadi et al., 1990; TDN(\%) $=-26.685+1.334(\mathrm{SK})+6.598(\mathrm{EE})+1.432(\mathrm{BETN})+0.967(\mathrm{PK})-$ $0.002(\mathrm{SK})^{2}-0.670(\mathrm{EE})^{2}-0.024(\mathrm{SK})(\mathrm{BETN})-0.055(\mathrm{EE})(\mathrm{BETN})-0.146(\mathrm{EE})(\mathrm{PK})$ $+0.039(\mathrm{EE})^{2}(\mathrm{PK})$

6) Hartadi et al., 1990; TDN(\%) = ME x 27,65

7) Dilaga, 1992

8) FAO, 2005 
Tabel 2. Komposisi dan kandungan nutrien ransum percobaan (\% dasar BK)

\begin{tabular}{lccc}
\hline \hline \multirow{2}{*}{ Bahan Pakan } & \multicolumn{3}{c}{ Perlakuan } \\
\cline { 2 - 4 } & P0 & P1 & P2 \\
\hline Rumput raja & 60 & 60 & - \\
Dedak padi & 31 & - & 31 \\
Dedak padi kukus & - & 31 & 0,1 \\
MHA & - & - & 2 \\
Vitamin dan mineral & 2 & 2 & 0,5 \\
Minyak sawit & 0,5 & 0,5 & 1,5 \\
Urea & 1,5 & 1,5 & 5 \\
Molases & 5 & 5 & 100,1 \\
\hline Jumlah & 100 & 100 & 15,95 \\
\hline Kandungan Nutrien ${ }^{1)}$ & & & 57,91 \\
\hline Protein Kasar & 15,97 & 15,97 & 1,24 \\
Total Digestible Nutrient & 57,97 & 57,97 & 1,07 \\
Kalsium & 1,24 & 1,24 & 25,78 \\
Fosfor & 1,08 & 1,08 & 0,21 \\
Serat Kasar & 25,80 & 25,80 & \\
Metionin & 0,13 & 0,13 & \\
\hline
\end{tabular}

Evaluasi kecernaan ransum dilakukan dengan menimbang pakan yang diberikan, sisa pakan dan feses selama 24 jam. Feses segar yang dihasilkan ditimbang, kemudian diambil $10 \%$ tiap ekor tiap harinya dan dikeringkan, dikomposit menjadi satu tiap ulangan dan dimixer hingga homogen. Feses yang telah diblender dianalisis kandungan bahan kering dan bahan organik. Semua data yang diperoleh dari penelitian dianalisis variansi berdasarkan rancangan acak lengkap (RAL) pola searah.

\section{HASIL DAN PEMBAHASAN}

\section{Konsumsi Ransum}

Rata-rata konsumsi bahan kering pada domba lokal jantan yang mendapat pakan perlakuan disajikan pada Tabel 3. Rata-rata konsumsi bahan kering domba lokal jantan selama penelitian masing masing perlakuan $\mathrm{P} 0$, P1, dan P2 berturut-turut adalah 960,024; 909,462; dan 926,399 g/ekor/hari. Hasil analisis variansi menunjukan bahwa pengukusan dedak padi dan suplementasi MHA berbeda tidak nyata $(\mathrm{P}>0,05)$ terhadap konsumsi bahan kering domba lokal jantan. Pengukusan dedak padi dan suplementasi MHA dalam ransum tidak mempengaruhi konsumsi bahan kering domba lokal jantan. Pengukusan dedak padi dan suplementasi MHA dalam ransum tidak mempengaruhi konsumsi bahan kering domba lokal jantan. Pengukusan dedak padi dan penambahan MHA pada ransum perlakuan belum mampu meningkatkatkan konsumsi bahan kering domba penelitian. Tinggi rendahnya konsumsi pakan dipengaruhi oleh palatabilitas (Parakkasi, 1983). Palatabilitas adalah segi kepuasan atau kesenangan dari suatu pakan (Soebarinoto et al., 1991).

Menurut Dilaga (1989) bahwa penambahan MHA dapat meningkatkan fermentasi selulosa dan glukosa, serta mempercepat laju pertumbuhan mikroba rumen dan memacu kecernaan karbohidrat, meningkatkan sintesis protein mikroba. Mugiyono dan Karmada (1989), menyatakan bahwa kemampuan ternak untuk mengkonsumsi pakan sangat dipengaruhi oleh berat badan, umur, jenis kelamin, lingkungan, kesehatan, dan mutu pakan. Rata-rata konsumsi bahan organik pada domba lokal jantan yang mendapat pakan perlakuan disajikan pada Tabel 4. 
Tabel 3. Rata-rata konsumsi bahan kering domba lokal jantan (g/ekor/hari)

\begin{tabular}{cccccc}
\hline \hline \multirow{2}{*}{ Perlakuan } & \multicolumn{4}{c}{ Ulangan } & \multirow{2}{*}{ Rata-rata } \\
\cline { 2 - 5 } & 1 & 2 & 3 & 4 & \\
\hline P0 & 968,163 & 965,926 & 988,110 & 917,896 & 960,024 \\
P1 & 912,557 & 933,943 & 891,753 & 899,595 & 909,462 \\
P2 & 948,598 & 930,317 & 955,836 & 870,847 & 926,399 \\
\hline
\end{tabular}

Tabel 4. Rata-rata konsumsi bahan organik domba lokal jantan (g/ekor/hari)

\begin{tabular}{cccccc}
\hline \hline \multirow{2}{*}{ Perlakuan } & \multicolumn{4}{c}{ Ulangan } & \multirow{2}{*}{ Rata-rata } \\
\cline { 2 - 5 } & 1 & 2 & 3 & 4 & \\
\hline P0 & 842,781 & 829,702 & 847,355 & 780,304 & 825,036 \\
P1 & 773,885 & 791,716 & 759,152 & 765,906 & 772,665 \\
P2 & 819,069 & 794,046 & 828,417 & 743,366 & 796,225 \\
\hline
\end{tabular}

Rata-rata konsumsi bahan organik domba lokal jantan selama penelitian berturutturut dari P0, P1 dan P2 adalah 825,036; 772,665 dan 796,225g/ekor/hari. Hasil analisis variansi menunjukan bahwa pengukusan dedak padi dan suplementasi MHA berbeda tidak nyata $(\mathrm{P}>0,05)$ terhadap konsumsi bahan organik pakan domba lokal jantan. Pengukusan dedak padi dan suplementasi MHA dalam ransum tidak mempengaruhi konsumsi bahan organik domba lokal jantan.

Konsumsi BO sejalan dengan konsumsi bahan kering yang berbeda tidak nyata. Hal ini sesuai dengan pendapat Kamal (1994) yang menyatakan bahwa konsumsi bahan kering memiliki korelasi positif terhadap konsumsi bahan organiknya yaitu apabila ransum perlakuan tidak mempengaruhi konsumsi bahan kering maka ransum perlakuan tersebut tidak mempengaruhi konsumsi bahan organiknya.

Menurut Tillman et al. (1991), bahan organik merupakan bahan yang hilang pada saat pembakaran. Nutrien yang terkandung dalam bahan organik merupakan komponen penyusun bahan kering. Komposisi bahan organik terdiri dari lemak, protein kasar, serat kasar, dan BETN. Bahan kering, komposisi kimianya sama dengan bahan organik ditambah abu (Kamal,1994). Akibatnya jumlah konsumsi bahan kering akan berpengaruh terhadap jumlah konsumsi bahan organik.

\section{Kecernaan Ransum}

Rata-rata kecernaan bahan kering domba lokal jantan selama penelitian dapat dilihat pada Tabel 6. Rata-rata kecernaan bahan kering domba lokal jantan selama penelitian berturut-turut dari P0, P1 dan P2 adalah 72,424; 73,050 dan 73,068 \%. Hasil analisis variansi menunjukkan bahwa pengaruh perlakuan terhadap KcBK berbeda tidak nyata $(\mathrm{P}>0,05)$. Pengukusan dedak padi dan suplementasi MHA dalam ransum tidak mempengaruhi KcBK domba lokal jantan.

Pengukusan akan mengakibatkan sel - sel pati mengembang dan juga terjadi penguraian granula pati. Ikatan pati akan longgar sehingga terjadi pembebasan amilosa yang akan menyebabkan daya larutnya meningkat (Manik, 1985). Kualitas dedak padi ditentukan oleh tinggi rendahnya kandungan serat kasar. Dedak padi tersusun dari sekam, lembaga, selaput putih beras, menir dan pati namun dedak padi yang digunakan merupakan dedak kasar sehingga memiliki kandungan sekam yang tinggi. Loosli (1969) cit Soebarinoto et al. (1991), membuktikan bahwa di dalam rumen 
Tabel 6. Rata- rata kecernaan bahan kering pada domba lokal jantan (\%)

\begin{tabular}{cccccc}
\hline \hline \multirow{2}{*}{ Perlakuan } & \multicolumn{4}{c}{ Ulangan } & \multirow{2}{*}{ Rata-rata } \\
\cline { 2 - 5 } & 1 & 2 & 3 & 4 & 72,424 \\
P0 & 70,078 & 74,311 & 70,097 & 75,212 & 73,050 \\
P1 & 74,678 & 70,351 & 73,031 & 74,140 & 73,068 \\
P2 & 70,370 & 73,803 & 74,802 & 73,298 & \\
\hline
\end{tabular}

Tabel 7. Rata- rata kecernaan bahan organik pada domba lokal jantan (\%)

\begin{tabular}{|c|c|c|c|c|c|}
\hline \multirow{2}{*}{ Perlakuan } & \multicolumn{4}{|c|}{ Ulangan } & \multirow{2}{*}{ Rata-rata } \\
\hline & 1 & 2 & 3 & 4 & \\
\hline P0 & 74,235 & 77,331 & 73,991 & 78,399 & 75,989 \\
\hline $\mathrm{P} 1$ & 77,824 & 73,736 & 76,400 & 77,262 & 76,306 \\
\hline $\mathrm{P} 2$ & 73,996 & 77,556 & 77,801 & 75,601 & 76,239 \\
\hline
\end{tabular}

domba yang diberi ransum murni bebas protein akan dapat membentuk 10 asam amino essensial. Sehingga dengan pemberian ransum yang memenuhi kebutuhan protein domba, akan mengakibatkan terpenuhinya kebutuhan asam amino domba. Hal ini dikarenakan mikroba rumen merupakan sumber protein bagi induk semang, Sehingga suplementasi MHA belum berdampak pada peningkatan kecernaan ransum.

Rata-rata kecernaan bahan organik domba lokal jantan selama penelitian dapat dilihat pada Tabel 7. Rata-rata kecernaan bahan organik domba lokal jantan selama penelitian berturut-turut dari P0, P1 dan P2 adalah 75,989; 76,306 dan 76,239\%. Hasil analisis variansi menunjukkan bahwa pengaruh perlakuan terhadap KcBO berbeda tidak nyata $(\mathrm{P}>0,05)$. Pengukusan dedak padi dan suplementasi MHA dalam ransum tidak mempengaruhi KcBO domba lokal jantan.

Menurut Tillman et al. (1991), kecernaan bahan kering dapat mempengaruhi kecernaan bahan organik dimana kecernaan bahan organik menggambarkan ketersediaan nutrien dari pakan dan menunjukkan nutrien yang dapat dimanfaatkan oleh seekor ternak. Menurut Kamal (1994) bahan kering terdiri dari lemak, protein kasar, serat kasar, BETN dan abu. Bahan organik merupakan bagian dari bahan kering. Hasil yang berbeda tidak nyata juga disebabkan karena konsumsi bahan kering dan konsumsi bahan organik yang sama. Menurut Tillman et al. (1991), bahwa adanya hubungan yang dekat antara kecernaan pakan dan konsumsinya. Kandungan nutrien pada setiap perlakuan hampir sama yaitu dengan kandungan TDN sekitar 57,91-57,97\%, protein kasar sebesar 15,95 - 15,97\% dan kandungan serat kasar antara 25,78-25,80\%.

\section{Nutritive Value Index Bahan Kering (NVIBK)}

Rata-rata NVIBK domba lokal jantan selama penelitian dapat dilihat pada Tabel 8. Rata-rata NVIBK domba lokal jantan selama penelitian berturut-turut dari P0, P1 dan P2 adalah 695,396; 664,932 dan 677,654 g/ekor/hari. Hasil analisis variansi menunjukkan bahwa pengukusan dedak padi dengan suplementasi MHA berbeda tidak nyata $(\mathrm{P}>0,05)$ terhadap NVIBK pada domba lokal jantan. Pengukusan dedak padi dan suplementasi MHA dalam ransum tidak mempengaruhi NVIBK domba lokal jantan.

NVIBK yang berbeda tidak nyata dikarenakan konsumsi bahan kering dan KcBK yang berbeda tidak nyata. NVI merupakan hasil kali dari konsumsi pakan dan kecernaan 
Tabel 8. Rata- rata NVIBK pada domba lokal jantan (g/ekor/hari)

\begin{tabular}{cccccc}
\hline \multirow{2}{*}{ Perlakuan } & \multicolumn{4}{c}{ Ulangan } & \multirow{2}{*}{ Rata-rata } \\
\cline { 2 - 4 } & 1 & 2 & 3 & 4 & \\
\hline P0 & 678,772 & 718,392 & 693,463 & 690,959 & 695,396 \\
P1 & 682,017 & 658,190 & 651,624 & 667,897 & 664,932 \\
P2 & 668,083 & 687,739 & 715,790 & 639,003 & 677,654 \\
\hline
\end{tabular}

Tabel 9. Rata- rata NVIBO pada domba lokal jantan (g/ekor/hari)

\begin{tabular}{cccccc}
\hline \hline \multirow{2}{*}{ Perlakuan } & \multicolumn{4}{c}{ Ulangan } & \multirow{2}{*}{ Rerata } \\
\cline { 2 - 4 } & 1 & 2 & 3 & 4 & \\
\hline P0 & 625,841 & 642,046 & 627,514 & 612,174 & 626,894 \\
P1 & 602,655 & 584,629 & 580,247 & 592,410 & 589,985 \\
P2 & 606,437 & 616,636 & 645,033 & 562,490 & 607,649 \\
\hline
\end{tabular}

relatifnya. NVI digunakan untuk menduga jumlah konsumsi zat-zat makanan tercerna (Soebarinoto et al., 1991).

Jumlah nutrien yang diserap berkaitan dengan isi rumen dimana peningkatan konsumsi sejalan dengan peningkatan kecernaan. Pengukusan dedak padi dan suplementasi MHA tidak mampu memperbaiki kualitas pakan, sehingga kualitas pakan tiap perlakuan sama. Hal ini menyebabkan konsumsi bahan kering dan kecernaan bahan kering berbeda tidak nyata sehingga tidak mempengaruhi kecepatan pencernaan dan aliran pakan pada setiap perlakuan. Sehingga jumlah pakan yang terserap dalam saluran pencernaan adalah sama pada setiap perlakuan. Tillman et al. (1991) menyatakan bahwa makin banyak bahan yang tidak dapat dicerna melalui saluran pencernaan yang berarti lebih lambat alirannya menyebabkan lebih sedikit ruangan yang tersedia untuk penambahan pakan.

\section{Nutritive Value Index Bahan Organik (NVIBO)}

Rata-rata NVIBO domba lokal jantan selama penelitian dapat dilihat pada Tabel 9. Rata-rata NVIBO domba lokal jantan selama penelitian berturut-turut dari P0, P1 dan P2 adalah 626,894; 589,985 dan 607,649 g/ekor/hari. Analisis variansi menunjukkan bahwa pengukusan dedak padi dengan suplementasi MHA berbeda tidak nyata $(\mathrm{P}>0,05)$ terhadap NVIBO pada domba lokal jantan.

NVIBO yang berbeda tidak nyata dikarenakan konsumsi bahan organik dan KcBO yang berbeda tidak nyata. NVI merupakan hasil kali dari konsumsi pakan dan kecernaan relatifnya. NVI digunakan untuk menduga jumlah konsumsi zat-zat makanan tercerna (Soebarinoto et al., 1991). Bahan organik merupakan bagian dari bahan kering. Bahan organik terdiri dari lemak, protein kasar, serat kasar, BETN.

Kandungan nutrien pada setiap perlakuan hampir sama yaitu dengan kandungan TDN sekitar 57,91-57,97\%, protein kasar sebesar 15,95 - 15,97\% dan kandungan serat kasar antara 25,78 - 25,80\%. Kandungan bahan organik yang sama, mengakibatkan jumlah konsumsi pakan tidak berbeda nyata. Ternak akan berhenti makan jika kebutuhan nutrisinya telah tercukupi. Kualitas pakan perlakuan hampir sama, dimana pengukusan dan suplementasi MHA tidak mampu melunakkan jaringan dedak padi dan meningkatkan kualitas pakan. Hal ini akan menyebabkan kecernaan yang berbeda tidak nyata. Selanjutnya akan menyebabkan jumlah pakan yang terserap dan tidak keluar melalui feses adalah sama, sehingga berbeda tidak nyata. 


\section{KESIMPULAN}

Dari pembahasan di atas, maka dapat diambil kesimpulan bahwa pengukusan dedak padi dan suplementasi MHA tidak menurunkan konsumsi bahan kering, konsumsi bahan organik, kecernaan bahan kering, kecernaan bahan organik, NVIBK dan NVIBO.

\section{DAFTAR PUSTAKA}

Belasco, J.C. 1954. New nitrogen coumpound for ruminant A laboratory Evaluation. J.Anim. Sci. 13 : $601-610$.

Dilaga, S. H. 1992. Penggunaan Analog Hidroksi Metionin Dalam Ransum Pertumbuhan Awal Anak Jantan Sapi Holstein. Program Pascasarjana. Institut Pertanian Bogor. Bogor.

FAO. 2005. Animal Feed Resources Information System.

http://www.fao.org/ag/aga/agap/frg/afris/data/3 61.HTM diakses tanggal 22 Juni 2010.

Hartadi, H., S. Reksohadiprodjo dan A. D. Tillman., 1990. Tabel Komposisi Pakan untuk Indonesia. Gadjah Mada University Press. Yogyakarta.

Kamal, M. 1994. Nutrisi Ternak I. Gadjah Mada University Press.Yogyakarta.

Kamal, M. 1998. Bahan Pakan dan Ransum Ternak. Gadjah Mada University Press. Yogyakarta.
Kearl, L.C., 1982. Nutrient Requirements Of Ruminant In Developing Countries. International Feedstuff. Institute Utah Agricultural Experiment Station. Utah State University. Logan Utah.

Manik, I.G. 1985. Pengaruh Pengukusan Ubi Kayu Dalam Campuran Dengan Urea Sebagai Ransum Penguat Terhadap Metabolisme Glukosa, Nitrogen Dan Energi Pada Kambing Menyusui Dan Tidak Menyusui. Program Pascasarjana Institut Pertanian Bogor. Bogor.

NRC. 2001. Nutrient Requirement of Dairy Cattle. Seventh Revised Edition. National Academy Press. Wahington.

Soebarinoto, S. Chuzaemi dan Mashudi. 1991. Ilmu Gizi Ruminansia. Jurusan Nutrisi dan Makanan Ternak. Fakultas Peternakan Universitas Brawijaya. Malang.

Tillman, A.D., H. Hartadi., S. Reksohadiprodjo., S. Prawirokusumo., dan S Lebdosoekojo. 1991. Ilmu Makanan Ternak Dasar. Gadjah Mada University Press, Yogyakarta.

Williamson, G. dan Payne, A. 1993. Pengantar Peternakan di Daerah Tropis. Terjemahan oleh: IGN Djiwa Darmadja. Gadjah Mada University Press. Yogyakarta.

Yitnosumarto, S. 1993. Percobaan, Perancangan, Analisis, dan Interprestasinya. Gramedia. Jakarta. 